\title{
Recent biological techniques for diagnosis of Chlamydophila abortus in aborted goats
}

\author{
Wafaa A. Osman*, Azza S. A. Goda, Mona A. Mahmoud, T. R. Abou EL \\ Naga
}

Department o Animal Health, Desert Research Center, Cairo

\begin{abstract}
Chlamydophila abortus ( $C$. abortus) is one of the most important causative agents of enzootic abortion which has been caused a serious economic problem in domesticated and wild ruminants world wide. This study was aimed to diagnose $C$. abortus infection in aborted goats in Ras Suder Research Station (South Sinai) - Desert Research Center from 2004-2006. Twenty aborted cases from 130 pregnant nannies were recorded and examined serologically using complement fixation test (CFT). Eighty percent (16/20) of the aborted cases were serologically positive and $20 \%(4 / 20)$ randomly collected from apparently healthy pregnant nannies were also had antibodies against $C$. abortus. Pathological lesions were detected. Ten aborted fetal samples from serologically positive aborted nannies were subjected to diagnosis using Polymerase Chain Reaction (PCR) showed positive results at $119 \mathrm{bp}$. According to this result, PCR proved to be feasible, reliable, specific and sensitive diagnostic tool in diagnosis of $C$. abortus infection.
\end{abstract}

Chlamydophila abortus (C. abortus) is a Gram-negative intracellular bacterium that was formerly known as Chlamydia psittaci serotype 1 (Everett et al., 1999). It is considered as one of the most economically important pathogens of domesticated and wild animals, which cause abortion, weak neonates, fetal loss and infertility in sheep, goats and cattle in many countries around the world (Nietfeld, 2001; De Garves, et al., 2004; Da Silva et al., 2006). The bacterium is also a zoonotic agent that causes abortion and other clinical symptoms in human (Pospischil et al., 2002; Walder et al., 2003 and 2005). The main source of $C$. abortus in the environment is placenta and fetal fluids of affected animals, elementary bodies remained infectious for several days (Papp et al., 1994). The route of transmission between animals is mostly fecaloral and the infection is asymptomatic or at the best oligosymptomatic in non-pregnant animals and during pregnancy (Borel, 2008). Few reports suggested inhalation as another route of transmission (Jones and Anderson, 1988). Based on experimental findings, venereal transmission was suggested as a less common route of transmission (Applayard et.al., 1985). Development of clinical signs due to C. abortus infection depends on, the time of infection (AlQudah et al., 2004). Sheep and goat infected 5-6 weeks before parturition can develop clinical disease during the current pregnancy (Morgan et al., 1988; Wilsmore et al., 1990). It was found that infected and latently infected sheep and goats may shed $C$. abortus in their reproductive tract for up to 3 years post infection (Morgan et al., 1988).

CFT is the most widely accepted serodiagnostic method for diagnosis of chlamydial infection in animals (Kaltenbook et al., 1997; Travnicek et al., 2001) as it gives satisfactory results with ovine, caprine and avian serum samples (Butty and Nicolet, 1987).

Pathological changes observed were subcutaneous petechial haemorrhages in the skin of legs, hips, neck and in the head of chlamydial aborted feti (Studdert, 1968). The necrotic placentitis is the primary pathological lesion of chlamydial infection in sheep and goats (Aitken, 1989).

PCR is a useful tool for the detection of Chlamydophila in biological samples (Laroucou et al., 2001; Wafaa, 2007). PCR makes it possible to process a large number of specimens, is easy to use, and provides rapid results, besides being safer than culturing the microorganism in cell substrates. PCR analysis using fresh or frozen samples in straight forward furthermore, PCR can be adopted for use on formalin fixed and paraffin-embedded samples, the methods permits samples to be kept for retrospective diagnosis from archival material and avoids the zoonotic risk of C. abortus (Nieves Ortega et al., 2007).

The purpose of the present study was to diagnose chlamydial infection by PCR, serology (CFT) and pathology.

\footnotetext{
* Corresponding author. Tel.: +20 01222830368 ;

E-mail address: wafaa1rana@yahoo.com

(Wafaa A. Osman).
} 
Animals. This study was carried out on 130 pregnant nannies located in Ras Suder Research Station, Desert Research Center; Samples were collected during the period from $2004-2006$.

Samples.

A- Serum samples. Blood samples were collected from 20 aborted nannies (4 weeks post abortion) and 20 blood samples randomly collected from apparently healthy pregnant nannies. Serum samples were separated and submitted to CFT to detect antibodies against C. abortus.

B- Tissue samples for gross examination and histopathological studies. Tissue samples were collected from placenta of aborted nannies and internal organs of aborted foeti (liver, kidneys, heart, brain, lung and spleen). The collected samples were fixed in 10\% neutral buffered formalin. The fixed specimens were then, washed, dehydrated and embedded in paraffin wax. The tissues were sectioned at 4-5 $\mu$ thickness and stained with haematoxylin and eosin (H\&E) for histopatholoical examination and stained with Gemeniz stain as special stain for C. abortus (Bancroft et al., 1996).

Antisera. Reference Antisera for Chlamydia ( $C$. abortus CFT Reagents, "Seiken") were obtained from Denka Seiken $\mathrm{Co}^{\circledR}$., Tokyo, Japan. Antisera were used for detection of chlamydial antibodies in the suspected materials.

Reference Chlamydial antigen. It was obtained from Denka Seiken Co ${ }^{\circledR}$., Tokyo, Japan. It was used for serological detection of antibodies.

Complement. Freeze dried preparation of preserved guinea pig serum (Welcome ${ }^{\circledR}$ ) was used in CFT.

PCR. From 10 serologically positive cases for chlamydiosis, tissue samples (placenta, internal organs of aborted feti as liver, kidneys, lung and brain) were subjected to PCR. After deparaffinizing of the paraffin embedded samples, the process of DNA extraction started.

DNA extraction. The genomic DNA was extracted from samples using Dneasy tissue kit purchased from QIA Gen ${ }^{\circledR}$, Basel, Switzerland according to (Venables et al., 1997).

PCR amplification of chlamydial DNA. It was performed on DNA extracted from tissue samples using oligonucleotide primers chla. $2 \mathrm{AF}$ and chla. 2Br according to (Sykes et al., 1997).

The expected band length is 119 bp. The amplification condition, the master mix and primers structure are as follows.

\begin{tabular}{lcccc}
\hline \multicolumn{1}{c}{ Constituent } & Initial Conc. & Amount $(\boldsymbol{\mu l})$ & Final Conc. & $\mathbf{X}^{8}$ \\
\hline Distilled $\mathbf{H}_{\mathbf{2}} \mathbf{O}$ & & 13.2 & & $105.6 \mu \mathrm{l}$ \\
Buffer & $\mathrm{X} 10$ & 2.0 & & $16.0 \mu \mathrm{l}$ \\
DNtps & $10 \mathrm{~m} \mathrm{M}$ & 0.4 & $0.2 \mathrm{mM}$ & $3.2 \mu \mathrm{l}$ \\
Tag polymerase & $5 \mu / \mathrm{Ml}$ & 0.4 & $2 \mu / \mathrm{Ml}$ & $3.2 \mu \mathrm{l}$ \\
Primere 2AF & $20 \mathrm{mM}$ & 1.0 & $1 \mathrm{mM}$ & $8.0 \mu \mathrm{l}$ \\
Primer 2Br & $20 \mathrm{mM}$ & 1.0 & $1 \mathrm{mM}$ & $8.0 \mu \mathrm{l}$ \\
Total volume & & $18.0 \mu \mathrm{l}$ & & $144.0 \mu \mathrm{l}$ \\
\hline
\end{tabular}

\section{Results}

\section{Primers:}

\section{AF 5- GCTTTTCTAATTTACACC-3}

\section{Br 5- ATAGGGTTGAGACTATCCACT-3}

Control: Distilled $\mathrm{H}_{2} \mathrm{O}$ as negative control and pure DNA of C. abortus as positive control. $2 \mu 1$ of template added to each tube and $2 \mu l$ of distilled $\mathrm{H}_{2} \mathrm{O}$ added to tube of negative control.

\section{Thermocycler adjustment:}

$\begin{array}{ll}1 / 95 \mathrm{C} & 10 \text { minutes } \\ 2 / 95 \mathrm{C} & 30 \text { seconds } \\ 3 / 50 \mathrm{C} & 30 \text { seconds } \\ 4 / 72 \mathrm{C} & 45 \text { seconds } \\ 5 / 72 \mathrm{C} & 10 \text { minutes } \\ 6 / 4 \mathrm{C} & \text { pause }\end{array}$

This program was used for 40 cycles.

Analysis results by electrophoresis on horizontal agrose gel $1.5 \%$.
History of the farm. The rate of abortion was high in the first year in the pregnant nannies and decreased in the following years.

Clinical signs. Abortion was the most prominent symptom in pregnant nannies at late stage of pregnancy at the first year while in the second year stillbirth and weak kids were the prominent signs.

Serological studies. Results of serological analysis were shown in Table (1).

Histopathological findings.

A- Fetal placenta. There was massive necrosis of chorioallantoic villi with sloughing of the trophoblastic cells covering of the villi into the crypts. In addition to inflammatory cells mainly neutrophils and macrophages were seen. Myxomatous degeneration of some chorioallantoic villi was observed (Photo 1). Severe hemorrhages in the intercotyledonary 
areas were seen. Marked signs of vasculitis were noticed. Chlamydial elementary bodies were detected in the cytoplasm of trophoblasts as red spherical granules in sections stained with Gimenez stain (Photo 2).

\section{B- Aborted fetal organs.}

Liver. Showed multiple foci of hepatic cell necrosis associated with diffuse infiltration of mononuclear cells; mostly lymphocytes in hepatic parenchyma (Photo 3). It appeared as bright red granules against blue back ground in section stained with Gimenez stain (Photo 4).

Lung. Displayed aggregations of neutrophils and macrophages in the lumen of alveoli (Photo
5). In addition to the alveolar walls were thickened, pulmonary blood vessels appeared dilated and congested.

Kidney. Showing extensive necrosis of epithelium lining of renal tubules also it, showing hypercellularity of renal glomeruli in addition to necrotic changes of epithelium lining of renal tubules (Photo 6 and 7).

PCR. Ten samples from placenta and aborted feti of aborted nannies which were serologically positive recorded positive results at $119 \mathrm{bp}$. The positive control showed the expected amplification product at 119 bp as shown in Photo (8).

Table (1): Results of CFT in aborted and apparently healthy pregnant nannies.

\begin{tabular}{|c|c|c|c|c|c|c|c|c|}
\hline \multirow[t]{2}{*}{ Animals } & \multirow{2}{*}{$\begin{array}{c}\text { No. of } \\
\text { examined } \\
\text { animals }\end{array}$} & \multicolumn{2}{|c|}{$\begin{array}{c}\text { No. of animals with } \\
\text { antibodies (CFT) }\end{array}$} & \multicolumn{5}{|c|}{ Titer of serum samples } \\
\hline & & No. & $\%$ & 1/8 & $1 / 16$ & $1 / 32$ & $1 / 64$ & $1 / 128$ \\
\hline Aborted nannies & 20 & 16 & 80 & - & - & 1 & 5 & 10 \\
\hline Apparently healthy nannies & 20 & 4 & 20 & 1 & 3 & - & - & - \\
\hline
\end{tabular}

Positive results $\geq 1 / 32$
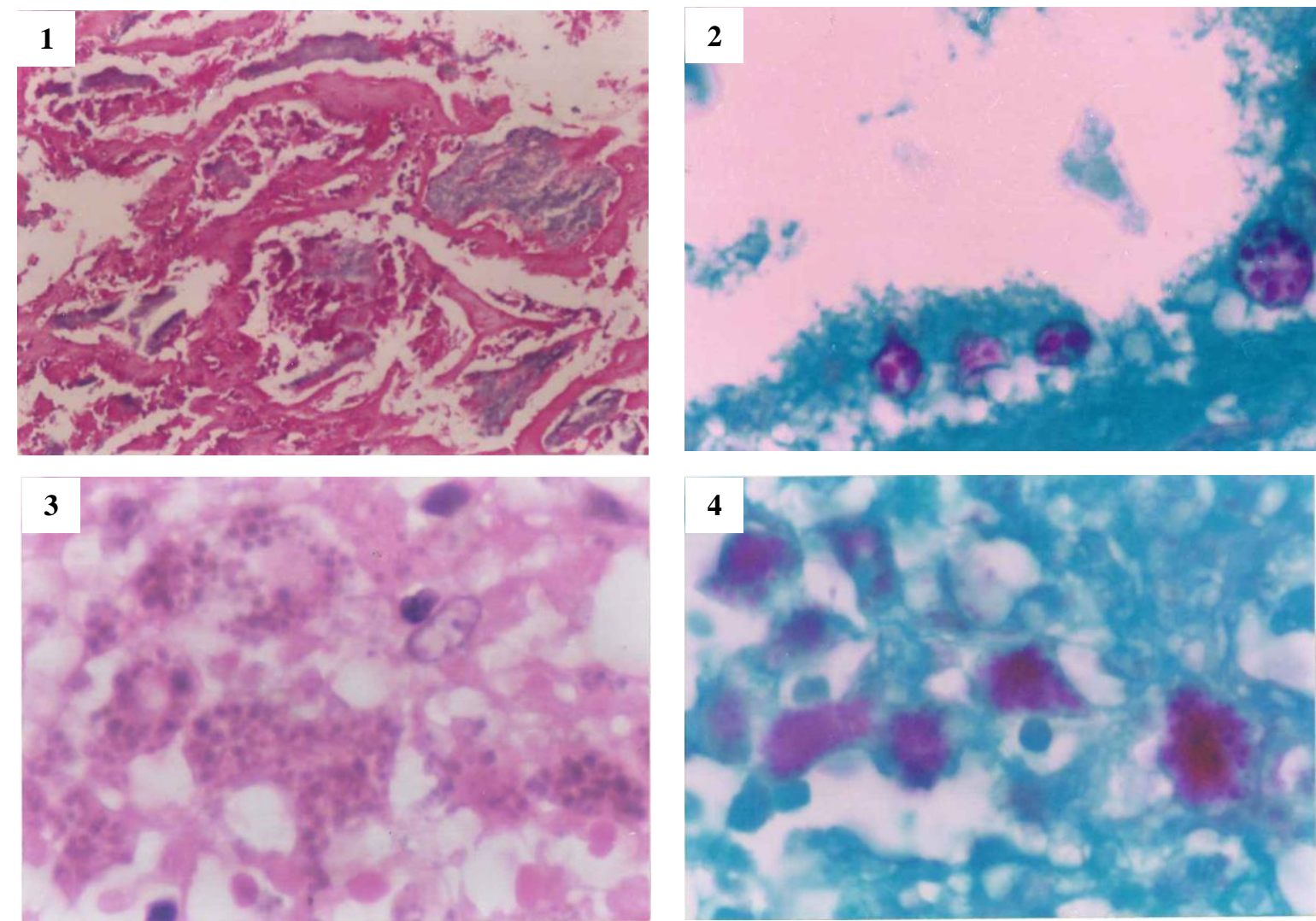

Photo (1): Fetal placenta, showing massive necrosis, myxomatosis of chorioallantoic villi and presence of inflammatory cells and cellular debris within the crypts (H \& E, X100).

Photo (2): Fetal placenta, showing presence of chlamydial elementary bodies within the trophoblast cells. (Gimenez stain, X 1000).

Photo (3): Liver of aborted foetus, showing presence of numerous chlamydial elementary bodies within the cytoplasm of hepatic cells (H\& E, X 1000).

Photo (4): Liver of aborted foetus, showing presence of intracytoplasmic chlamydial elementary bodies as bright red granules (Gimenez stain, X 1000). 

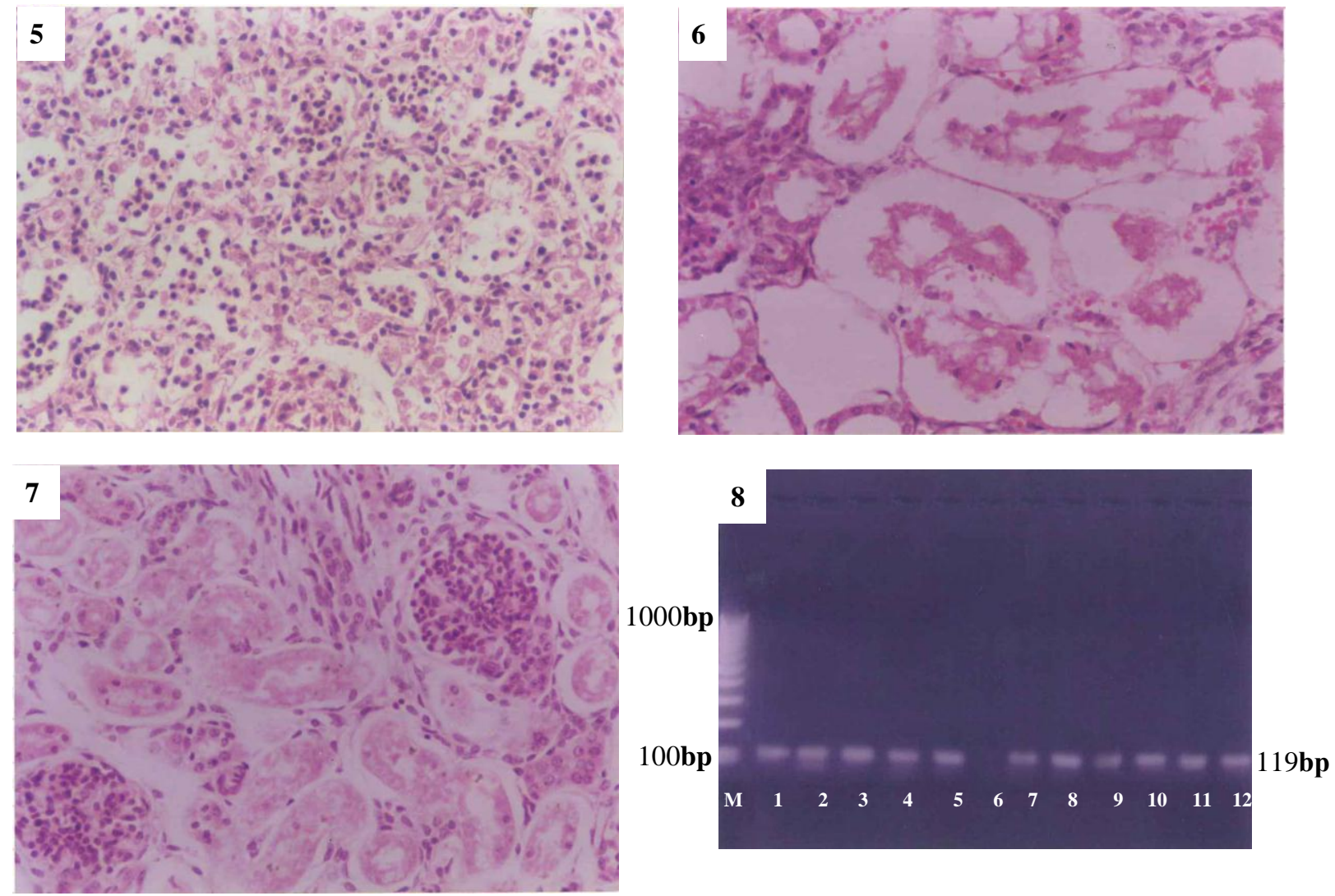

Photo (5): Lung of aborted fetus, showing aggregation of neutrophils and macrophages within the alveoli (H \&E, X200).

Photo (6): Kidney, showing extensive necrosis of epithelium lining of renal tubules (H \&E, X100).

Photo (7): Kidney, showing hypercellularity of renal glomereuli in addition to necrobiotic changes of epithilum lining of renal tubules (H \&E, X100).

Photo (8): PCR of (C. abortus) DNA from formalin-fixed and paraffin embedded tissues of aborted caprine feti (M, 100 bp ladder marker, lane 1-5 and 8-12 specific $C$. abortus PCR product (119bp detected). Lane 6 control negative and lane 7 control positive) .

The main histopathological findings in the placenta and aborted foeti of aborted nannies due to chlamydiosis were development of necrosis and inflammatory changes in internal organs. These were parallel with that of Buxton et al., (1990) and (2002); Chanton et al., (2002); Desouky et al., (2004). Such changes could be attributed to embolic dissemination of chlamydial infection from placenta (Buxton et al., 1990) as indicated by the presence of elementary bodies in the liver of aborted foeti. The initial interaction of Chlamydia with the host cells begins with the attachment of elementary bodies to the cells followed by phagocytosis within membrane limited vacuole called inclusion which don't fuse with lysosomes of cells and explain the survival of the organism in the intracellular environment (Escalante et al., 1998).

Regarding the advanced techniques for the diagnosis of $C$. abortus, ten randomly selected tissue samples of placenta and aborted foeti from serologically positive cases were subjected to PCR using both "2A" and "2B" primers which are specific for identification of $C$. abortus DNA. All the examined tissue samples showed the expected amplification product specific for C. abortus (119 bp). These findings were in parallel with that of Ongor et al., (2004); Nieves Ortega et al., (2007); Reitt et al., (2007); Wafaa, (2007); Da Silva et al., (2009) who reported that, PCR is the most adequate technique for the detection of $C$. abortus which is feasible, reliable, specific and sensitive diagnostic tool in diagnosis of $C$. abortus infection.

\section{Conclusion}

This study has clearly identified the need for more education and awareness about chlamydophilosis. Effective control of this disease is important not only because of its zoonotic importance, but also because of its adverse impact on animal production.

Oxytetracycline used by intramuscular route 105 and 120 day of pregnancy can prevent 
abortion but cannot prevent the Chlamydial shedding at kidding. Intervention by the government and the private sector through farmer training and awareness campaigns is therefore recommended.

\section{References}

Alaster Samkange.; Tendai C. Katsand.; Georgina .TZ. J.E. Crafford (2010): Seroprevalence survey of Chlamydophila abortus infection in breeding goats on commercial farms in the Otavi Veterinary District, Northern Namibia. Jornal of Veterinary Research vol. 77, pp.1-5.

Aitken, I. D. (1989): Animal Chlamydial abortion. Epidemiology 11-13.

Al-Qudah, J. M.; Sharif, L. A.; and Al-Domy, F. M. (2004): Seroprevalence of antibodies to Chlamydophila abortus shown in Awassi sheep and local goats in Jordan. Vet. Med. -Czech, 49, (12): 460-466.

Appleyard, W. T.; Aitken, I. D. and Anderson, I. E. (1985): Attempted venereal transmission of Chlamydia psittaci in sheep. Vet. Rec., 116, 535-538.

Bancroft, J. D; Stenvens, A and Turner, D. R. (1996): Theory and practice of histological techniques $4^{\text {th }}$ Ed., Churchill Livingstone, New York, Edinburgh, London, Melbourne, San Francisco, Tokyo.

Borel, N. (2008): Chlamydial abortion in ruminants. Serological, epidemiological and diagnostic investigations. University of Zurich, Vetsuisse Faculty.

Butty, F. B. and Nicolet, J. (1987): Chlamydiosis in Switzerland: Comparative study of diagnostic techniques. Schweizer Archivfur Tierheilkunde., 129 (1): 1-13.

Buxton, D., Barlow, R. M.; Anderson, I. E. and Mackellar, A. (1990): Observation on the pathogenesis of Chlamydia psittaci infection in pregnant sheep. J. Comp. Pathol., 102: 221-237.

Buxton, D.; Anderson, I. E.; Wattegdera, S. and Entrican, G. (2002): Ovine Chlamydial abortion characterization of the inflammatory immune response in placental tissues. J. of Comp. Pathology. 127: 2-3, 133-141. Chanton, G. H.; Thoma, R.; Corboz, L.; Borel, N. and Pospischil, A. (2002): Abortion in small ruminants in Switzerland: Investigations during two lambing seasons with special regard to chlamydia. SAT-Schweizer Archiv fur Tierheilkunde. 144: 9, 483-492.

Da Silva, F. G.; De Freitas, J. C. and Muller, E. E. (2006): Chlamydophila abortus in production animals. Cienc Rural, 36, 342-348.

Da Silva-Zacarias, F. G.; Alfieri,.; Lunardi, M. and Cesar, J. (2009): Validation of a PCR assay for Chlamydophila abortus rRNA gene detection in a murine model. Braz. Arch. Biol. Technol. V. 52 n. special: pp. 99106.

De Graves, F. J.; Gao, D.; Hehnen, H. R. and Kaltenboeck, B. (2003): Quantitive detection of Chlamydia psittaci and C. pecorum by high sensitivity realtime PCR reveals high prevalence of vaginal infection in cattle.J Clin Microbiol, 41, 1726-1729.

De Graves, F. J.; Kim, T. Y.; Jee, J. B. and Hehnen H. R. (2004): Reinfection with Chlamydophila abortus by uterine and indirect cohort route reduces fertility in cattle pre-exposed to Chlamydophila. Infect. Immun. 72, 5382545.

Desouky, H. M.; Abd-EI Razik, K. A and Ahmed Y. E. (2004): Diagnostic studies on ovine chlamydial abortion. J. Appl. Vet. Sci., NRC.1
Eisa, M.I. and Hamoda, f.k.(2002): Investigations on problem of Chlamydiosis among domestic and wild sheep. Assiut Vet. Med. J., 48(95): 76-90.

EsCalante-Ochoa, C.; Ducatell, R. and Haesebrouck, F. (1998): The intracellular life of $C$. abortus: how do the bacteria interact with the host cell? FEMS Microbiology Reviews, 22: 65-78.

Everett, K. D. E; Bush, R. M. and Andersen A. A (1999): Amended description of the order Chlamydiales, prosalof parachlamydiaceae fam. Nov. and Simkaniaceae fam .Nov. each containing one monotype genus, revised taxonomy of the family Chlamydiaceae, including a new identification of organisms. Int. J. Syst. Becteriol. 49, 415440.

Griffiths, P. C.; Plater, J. M. and Dawson, M. (1996): Serological diagnosis of ovine enzootic abortion by comparative inclusion immunofluorescence assay, recombinant lipoplysaccharide enzyme-linked immunosorbinat assay, and complement fixation test, J. Clin. Microbiol, 34, 1512-18.

Halil, I. G.; Cihan, K.; Oktay, G. and Mahmut, S. (2007): Seroprevalence of Chlamydophila abortus in aborting ewes and dairy cattle in north-east part of Turkey. Bull.Vet. Inst. Pulawy 51, 9-13.

Jones, G. E.; and Anderson, I. E. (1988): Chlamydia psittaci: Is tonsilar tissue the portalof entry in ovine enzootic abortion?. Res.Vet. Sci., 44, 260-261.

Kaltenbook, B.; Heard, D.; DeGraves, F. J. and Schmeer, N. (1997): Use of synthetic antigens improves detection by enzyme linked immunosorbent assay of antibodies against abortigenic Chlamydia psittaci in ruminants. J. Clinic. Microbiol., 35 (9): 2293 - 2298.

Kendrick, J. W. and Howarth, J. A. (1992): Reproductive infections. In the: Reproduction in farm animals, by Hafez. $6^{\text {th }}$ Ed., pp. 394,Lea and Febiger, Philadelphia, USA.

Laroucau, K.; Souriau, A. and Rodolakis, A. (2001): Improved sensitivity of PCR for Chlamydophila using pmp genes. Vet. Microbiol. 82: 155-164.

Longbotton, D.; Psarrou, E.; Livingstone, M. and Vretou, E (2001): Diagnosis of ovine enzootic abortion using an indirect ELISA (roM pg $1 \mathrm{~B}$ iELISA) based on a recombinant protein fragment of the polymorphic outer membrane protein PoMpg1B of Chlamydia abortus. FEMS Microbiology- Letters. 195: 2, 157-161.

Lydia, C.; Monika, H.; Daniela, K.; and Asteria, S. (2007): Occurrence of antibodies against Chlamydophila abortus in sheep and goats in the Slovak Republic. Ann. Agric Environ. Med. 14, 243-245.

Marsilio, F.; Martion, Bdi.; Francesco, C. Edi. And Meridiani, I. (2005): Diagnosis of ovine chlamydial abortion by PCR-RFLP performed on vaginal swabs. Vet. Research Communi., 29 (1): 99-106.

Masala, G.; Porcu, R.; Sana, G. and Tola, S. (2005): Role of Chlamydophila abortus in onine and caprine abortion in Sardinia. Vet. Res. Commun., 29,117-23.

Morgan, K. L.; Wills, J. M. and Howard, P. (1988): Isolation of Chlamydia psittaci from the gental tract of lambs: A possible links with enzootic abortion in ewes. Vet Rec., 123, 399-400.

Nietfeld, J. C. (2001): Chlamydial infections in small ruminants. Vet. Clin. North Am. Food Anim. Pract., 17, 301-314.

Nieves Ortega, J. A.; Navarro, L. N.; and Gallego, M. C. (2007): Evaluation of Chlamydophila abortus DNA extraction protocols for polymerase chain reaction diagnosis in paraffin-embedded tissues. J. Vet Diagn Invest 
19:421-425. O.I.E. (2000): Manual of standard for diagnostic tests and vaccine. 515- 521.

Öngör, H.; Çetinkaya, B.; Açik, M. N.; Karahan, M. and Bulut, H. (2004): Detection of Chlamydophila abortus in ovine milk by immunomagnetic separation-polymerase chain reaction. J. Vet. Med. B 50, 43-45.

Papp, J. R.; Shewen, P. E. and Gartly, C. J. (1994): Abortion and subsequent excretion of chlamydiae from the reproductive tract of sheep during oestrus. Infect. Immun., 62,3786-3792.

Pospischil, A.; Thoma, R.; Grest, P. and Gebbers, J. O. (2002): Abortion in humans caused by Chlamydophila abortus (Chlamydia psittaci serotype 1). Schweiz Arch Tierheilkd, 144, 463-466.

Quinlan, J. F. and McGuckin, P. K. (1999): Chlamydial abortion in a sheep flock: A case report. Irish Vet. J., 52 (12): 668-670.

Reitt, K.; Hibe, M.; Voegtlin A.; and Pospischil, A. (2007): Aetiology of bovine abortion in Switzerland from 1986to 1995 - a retrospective study with emph on detection of Neospora caninum and Toxoplasma gondii by PCR. $J$ Vet Med A Physiol Pathol Clin Med, 54, 15-22.

Rekiki, A.; SidBoumedine, K.; Souriau, A.; and Rodolakis, A. (2002): Isolation and characterization of local strains of Chlamydophila abortus (Chlamydia psittaci serotype 1) from Tunisia. Vet. Res., 33 (2): 215-222.

Rodolakis , A. (2001): Caprine clamydiosis. In: Tempesta, M. (ed): Recent advances in Goat Diseases.

Studdert, M. J. (1968): Bedsonia abortion of sheep II. Pathology and Pathogenesis with observation on normal ovine placenta. Res. Vet.Sci., 9: 57-64.

Sykes, J. E.; Studdert, V. P. and Anderson, G. (1997): Comparison of Chlamydia psittaci from cats with upper respiratory tract disease by polymerase chain reaction (PCR) of ompAgene. Vet. Rec., 140: 310-313.

Thedford, T. R. and Worman, F, D. (1990): The results of serological testing of goat blood for brucellosis, chlamydiosis, toxoplasmosis and bluetongue in three villages in the Tutume Agriculture District (Botswana), 1988-1989. ATIP- Working Paper wp-32, 4 pp.

Travnicek, M.; Kovacova, D.; Bhide, M. R; Zubricky, P. and Cislakova, L. (2002): Field evaluation of an iELISA and CF test for detection of IgG antibodies against Chlamydophila abortus in goats, sheep and rams. Vet. Med. -Czech. 47, (7): 195-198.

Travnicek, M.; Kovacova, D.; Zubricky, P. and Cislakova, L. (2001): Serosurvey of sheep and goats to Chlamydia psittaci in Slovakia during the year 1996-2000. Vet. Med. -Czech, 46, 281-285.

Venables, C.; Lysons, R.; Horigan, M. and Dawson, M. (1997): Bovine immunodeficiency-like virus: Inactivation in milk by pasteurization.Vet.Rec.,140: 75 .

Wafaa A. Osman (2007): Detection of Chlamydophila abortus in sheep by polymerase chain reaction . Bs. Vet. J. January vol. 17 No. 1, pp. 29-34.

Walder, G.; Hotzel, H.; Brezinka, C. and Ploner, F. (2005): An unusual cause of sepsis during pregnancy recognizing infection with Chlamydophila abortus. Obstet Gynecol, 106, 1215- 1217.

Walder, G.; Meusburger, H.; Hotzel, H.; Oehme, A. and Dierich, M. P. (2003): Chlamydophila abortus pelvic inflammatory disease. Emerg Infect. Dis., 9, 1642-1644.

Wilsmore, A. J.; Izzard, K. A. and Wilsmore, B. C. (1990): Breeding performance of sheep infected with Chlamydia psittaci (ovis) during their preceding pregnancy. Vet. Rec., 126, 40.

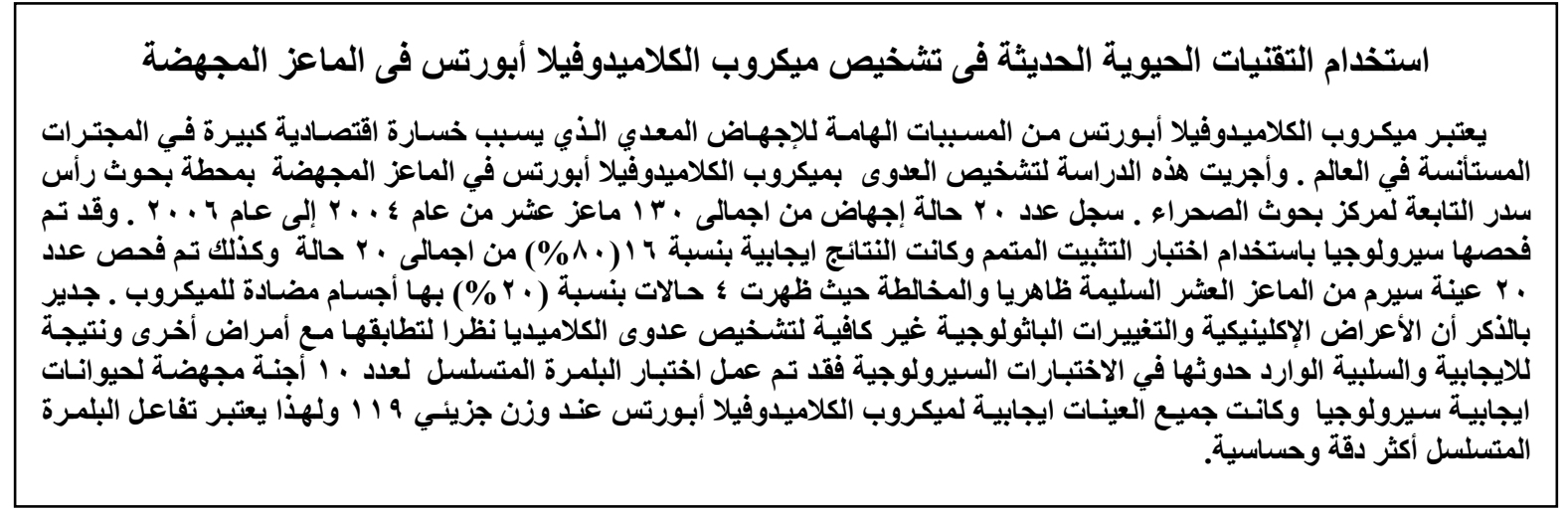

